Jurnal ASPIKOM, Vol. 6, No. 2, July 2021, pp. 292-302

P-ISSN: 2087-0442, E-ISSN: 2548-8309

DOI: http://dx.doi.org/10.24329/aspikom.v6i2.935

\title{
The Song \#2019GantiPresiden and Political Communication in Simulacra Analysis
}

\section{Lagu \#2019GantiPresiden dan Komunikasi Politik dalam Analisis Simulakra}

\author{
Dani Fadillah ${ }^{1 *}$, Jian Chang ${ }^{2}$ \\ ${ }^{1}$ Universitas Ahmad Dahlan, Jl Kapas, Semaki, Umbul Harjo, Yogyakarta, Indonesia \\ ${ }^{2}$ Nanjing Normal Uniiversity, 122 Ninghai Rd Gulou, Nanjing, Jiangsu, China \\ *Corresponding author, e-mail: dani.fadillah@comm.uad.ac.id
}

\begin{abstract}
This research aims to find out how the hashtag \#2019GantiPresiden, which was initially just a common hashtag on Twitter, has triggered a massive mass movement in Indonesia. Moreover, the hashtag incarnated into various souvenirs, even into a song that shouted the need for Indonesia to have a new president. The Hashtag \#2019GantiPresiden became a medium of communication to convey political messages from political actors and those interested in the Indonesian presidential elections in 2019. Qualitative method was used in the drafting of this paper by collecting data relating to the topic of discussion and then using the Simulacra logic initiated by Jean Baudrillard in data analysis. The study concluded that in 2019, the \#2019GantiPresiden hashtags showed the world that a voice on social media could become a great mass power in the real world.
\end{abstract}

Keywords: Hashtag; Indonesia; Music; Political communication

\begin{abstract}
Abstrak
Penelitian ini bertujuan untuk mengkaji bagaimana tagar \#2019GantiPresiden yang pada awalnya merupakan sebuah tagar biasa di media social Twitter berubah menjadi sebuah gerakan massa yang sangat masif di Indonesia. Bahkan sampai menjelma menjasi berbagai jenis sofenir hingga menjadi musik yang menyuarakan bahwa Indonesia perlu memiliki pemimpin baru. Tagar \#2019GantiPresiden menjadi media komunikasi yang membawapesanpesan politik dari aktor politik yang memiliki kepentingan di pemilihan umum 2019. Penelitian ini dilakukan dengan pendekatan kualitatif, data yang dikumpulkan kemudian kemudian didiskusikan dan dibedah menggunakan logika simulakra yang dicetukan oleh Jean Baudrillard. Kesimpulan dari penelitian ini meemperlihatkan bahwa pada tahun 2019 tagar 2019GantiPresiden yang tadinya hanya sebuah pesan di media social mampu menjelama menjadi kekuatan sipil yang sangat besar di dunia nyata.
\end{abstract}

Kata Kunci: Indonesia; Komunikasi Politik; Musik; Tagar 


\section{Introduction}

Communication in post-modern era has expanded beyond the limit (hypercommunication). The growth of communication continues uncontrollably with high speed, with a variety of forms, styles, and variations (talk-show, chat, Fan talk, star gathering, quiz) so that it has lost its purpose, function, and meaning in building a quality human life. The definition of a critical message in communication has now disappeared through the imagery, while the mark is just a game of sign and pleasure. The form of post-modern communication develops increasingly rapidly with various types. However, with its speed and variety of ways, it has lost its direction and purpose. Baudrillard uses the term hyperreality to explain the condition of reality (communication) beyond this (Fadillah, 2020b).

\#2019GantiPresiden hashtag that adds to the political constellations of the presidential election of the Republic of Indonesia 2019 had become an enormous mass movement. Hashtags that were initially tweeted by Partai Keadilan Sejahtera (Prosperous Justice Party) Politician Mardani Ali Sera, on his Twitter account, had managed to make many people down the street voicing the need to emerge new leaders who replace the incumbent. The hashtag of the political message also appeared on various merchandise ranging from clothing, hats, and pins to songs that voiced political parties as contained in the hashtag (Fadillah et al., 2019). However, it must be realized beforehand that the spread of the \#2019ChangePresident hashtag on social media is something normal as currently, social media is a medium for conveying aspirations for people living in a democratic society (Yuliarti, 2020). Nevertheless, it cannot be denied that there is much fake news on social media related to information on the political world (Mansur et al., 2021).

On May 19, 2018, on various Youtube channels, there were uploads of songs titled 2019 Ganti Presiden (literal translation: 2019 Change President) (\#2019GantiPresiden, 2018). The music not known that the original author of this song alleged that the songwriter was Jhon Paul Ivan, the former vocalist of Boomerang, but in question later rejected the news. Lastly, the songwriters were the Jhon Sang Alang, musicians who have long played in the Indonesian World of Music (Kardi, 2018). At the same time, the Youtube Style Voice account uploaded a video clip that supported the map with the title "I do not want to change President" (Style Voice, 2018). This song became the antithesis of the song 2019 Ganti Presiden that has appeared a few moments earlier. However, this is common; cyber warfare on social media is not free from the war of opinion and discourse in the real world (Syahputra, 2017). Even in the years 2014 ago, there have been many songs from several musicians of the homeland who hinted support on the land.

So, in this viral phenomenon, politically charged music can be said to be the Indonesian society's support for the candidates contesting in the 2019 presidential elections. Thus, this implies the rise of the two bargain positions among the free voters or just as normal movement and ordinary music without having any influence. Besides, the music requirements with political support are also a reference to explaining the current position of music in the constellation of politics in Indonesia, especially during the presidential election of 2019, and referring to the \#2019GantiPresiden movement and the song 2019 Ganti Presiden as a catalyst for the rising bid position (Handari, 2019).

In previous research, there were studies entitled Hyper Realitas Simulakra Tagar \#2019GantiPresiden Dalam Pemilihan Presiden Indonesia 2019 (Fadillah, 2019), 
Komunikasi Politik Gerakan \#2019GantiPresiden (Sujoko, 2019), Pemilu Pros and Cons of the Hashtag Movement \# 2019GantiPresiden as a Means of Campaigns in Elections (Fitri, 2018). Still, these studies discuss how social movements and public opinion are formed from the rampant hashtag \#2019GantiPresiden. At the same time, this research focuses on debating the \#2019GantiPresiden song, which is not a phenomenon of political communication in the Indonesian music industry. Therefore, what is new in this study is that this research focuses more on discussing each element that arises from the hashtag \#2019GantiPresiden phenomenon, namely music element. In addition, previous research examined too broadly.

The hyper-reality of \#2019GantiPresiden movements separated from the communication media technology that leads to the direction of simulation technology. In communication, communication has detached from the unreferenced reality without requiring a foundation of meaning, logic of purpose, and basis of value. Communication 'appears and disappears' instantaneously at high speeds in its orbit, without regard to the conditions and actual needs of the community is the education of communication.

According to Baudrillard, the primary function of the objects of consumption is not on the usefulness or the merits, but instead in the role of the signs or symbols disseminated through the advertisements of various media lifestyles (Jean Baudrillard, 2017). What we buy, no more than the signs instilled into the consumption objects, distinguishes the personal choices of one another. Specific lifestyle themes, individual classes, and prestige are the meanings implanted into consumption purposes. In other words, consumption objects have now become transformed into a set of status classification systems, prestige, and even community behavior (Fadillah, 2020a).

Furthermore, Baudrillard developed further his idea of the consumption position in a consumer society. According to him, consumption has become a fundamental factor in the ecology of human species (Schor et al., 2000). Baudrillard states that the mechanism of the consumption system necessarily departs from the operation of values and symbols and not because of the needs or desires of enjoyment (Baudrillards, 2018). With this statement, Baudrillard does not mean denying the importance of necessity. He wants to say that in a consumer society, consumption is a system of packaging governed by the need factor or desire of enjoyment, by a set of attractions to gain honor, prestige, status, and identity through a marking mechanism.

A thriving consumer society today is a society that runs social logic consumption, where usability and service are not the last motive of consumption action but rather the production and manipulation of social markers. Individuals receive their identity in conjunction with others not from whom and what it does but from the signs and meanings they consume, have, and show in social interactions. In a consumer society, a sign is a reflection of the most convincing individual self-actualization.

Through both of these books, Baudrillard expressly rejects Marx's (use-value) and Exchange-value principles and states that human consumption activity is essentially a non-utilitarian activity. He adopted the opinions of Mauss and Bataille that in institutions such as Kula and Potlach in primitive societies, the habit of giving things and spending something turned out to be more based on prestige and pride symbolically, not on usability. This is the principle that is now increasingly transparent in people's consumption activities today.

In 1988, the work of magnum opus Baudrillard, Simulations, was published. In this soon-to-classic book, Baudrillard inspired a characteristic of Western society's cultural character today. According to him, Western culture today is a representation of 
the simulation world. This world is formed from the relationship of various signs and codes randomly, without explicit relational references. This relationship involves a real sign (fact) created through the production process, as well as a pseudo-mark (imagery) created through the reproduction process (Baudrillards, 1988).

In simulated cultures, the two signs accumulate and are interwoven together and form a single unit. It can no longer be recognized which of the original, the real, and the false, the pseudo. Everything is a part of the reality that is lived and lived by Western society today. This unit is called by Baudrillard as Simulacra or simulacrum, a World that awakens from the complicated values, facts, marks, imagery, and code. Reality no longer has a reference, except Simulacra itself. In the post-modern era, the principle of simulation becomes commander in chief, where reproduction (with information technology, communication, and industry of knowledge) replaces production policy. At the same time, game marks and imagery dominate almost the entire process of communication Human.

In this simulation community like this, everything is determined by the relationship of signs, imagery, and code. The identity of a person, for example, is no longer defined by and from within itself. Character is determined by the crossconstruction of the mark, imagery, and code that mirror how individuals understand themselves and their relationship with others.

In the simulation world, it is not a reality that mirrors reality, but rather models offered television, advertising, or cartoon figures. Places like Disneyland or Universal Studios, Movie stars like Angelina Jolie or a singer like Justin Bieber, An ad for Levis pants or a Guess watch, Star Wars Movies, Barbie dolls, Spiderman cartoons, or even Minions are now models of reference in building imagery, values and meaning in the social, cultural and political life of society today.

In the simulation discourse, humans inhabit a space of reality, where the difference between the real and the fantasy, the original and the false, is fragile. Humans now live in a real fantasy space of factual fiction. Simulated realities become a new space of life where humans discover and actualize their existence. Through television, for example, the simulation world performs perfectly. This is a space that is no longer concerned with real categories, false, true, wrong, reference, representation, fact, image, production, reproduction, and everything is melting into one cross the complicated mark.

According to Baudrillard, the reality of the simulation produced by various new technologies - Microprocessor, memory bank, remote control, telecard, laser disc, optic cable, drone - has defeated the real reality even become a reference model New to society. Imagery is more convincing than fact, and dreams are more believable than everyday truth. This is the world of hyperreality: a reality that is more tangible than real, pseudo, and explosiveness.

In the world of hyperreality, the original objects are the result of production struggling into one with hyperreal objects, which are the result of reproduction. Hyperrealities, such as online media, Facebook, Twitter, Disneyland, shopping malls, and television, seem to be more real than actual reality, where models, imagery, and Hyreals code have metamorphized as mind controllers and human beings (Douglas Kellner, 2007).

With mass media, for example, artificial reality (imagery) seems to be more real than the actual truth. Further, false reality (imaging) now no longer has its origins, references, or depth of meaning. Fictional characters who are all artificial imagery - are 
an unreferenced reality but appear to be closer and more real than the existence of our relatives or friends. In such conditions, reality, truth, fact, and objectivity lose its life. Hyperreality is reality itself, an era led by models of reality without origin and reference, where the reality is not merely reproducible but always and always reproduced

\section{Method}

The method used in this research was qualitative research with a qualitative descriptive research design (Rijali, 2019). The study useds a critical discourse analysis of Pecheux approaches, while the model of analytical methods used is a framework of discourse from Sara Mills (Eriyanto, 2001). In studying the problem of research, Jean Baudrillard's Simulacra theory was used. The Simulacra theory was used to discuss the existing signs. The representation presented from the music can build a simulation world that will provide a hyperreality effect, which can later affect the candidates' positions for the president-Vice president candidate in the community's eyes. Also, Michael Foucault's theory of power was used because of the interconnectedness of previous approaches. The simulation world can present a specific power effect, as the skills intended by Michael Foucault. The influence of the figure, in this case, musicians, can also be explained through this perspective. As a supporter, music theory as a propaganda media initiated by John Street was also used to study the role of politicalinspired music representing the role of music in the 2019 election.

Unlike quantitative research based on numerical and statistical calculations, qualitative research has a descriptive basis for understanding a phenomenon in depth. Qualitative research uses a theoretical basis as a guide to focusing on research and highlighting the processes and meanings found in the phenomenon (Strauss, 2003). The most fundamental difference between quantitative and qualitative research is the theory and data flow, where quantitative research stems from the theories evidenced by field data; while qualitative research departs from the field data and uses the existing theory as a supporter, then the results will bring about the theory of the data (Noeng Muhadjir, 1996).

\section{Results and Discussion}

There are several reasons in the point of view Simulacra why the Movement \#2019GantiPresiden and the songs of 2019 Ganti Presiden that were full of the nuance of political support are quite successful as a medium of political communication during the period of the Indonesian 2019 presidential election campaign.

First, the Simulacra analysis of political campaigns as one of the agendas to gain power also led to power in the process if viewed through Foucault's power theory goggles. The way to achieve that power done by winning the discourse. The method of earning a discussion in the Post-modern society that thirst for consumption through visual representation, a game of omens that can become a simulation, becomes an absolute necessity.

The Song 2019 Ganti Presiden, which can draw the public's attention to attend and participate voluntarily, certainly was qualified to create a simulation on the community. The Song 2019 Ganti President was moved into a different medium of a political campaign because it shows good moral gestures in Indonesia's middle of money politics. The message conveyed here is that a supported candidate in the 2019 change of president has gained support from sincere people with a shared vision 
because they are present at this event voluntarily.

These signs are formed and simulated to the point where we no longer know the real or not because the imagination/sign itself has melted with reality, becoming hyperreality. In this case, the community gets the stimulus that the movement \#2019GantiPresiden supported by sincere people. Yet, this is only a reflection of some of the whole thing, not the entire. It is not the fact nor the actual reality, but instead it is created through simulation. The \#2019GantiPresiden movement is supported by clean, sincere, people who have a shared vision of those who volunteer for movement \#2019GantiPresiden may not just stop at those limits because of the effects of hyperreality. Hyperreality will reconstruct a new reality of good from what there is not to be as authentic and as real as it is. The hyperreality that may occur in the \#2019GantiPresiden movement also describes that those who elect a candidate supported by the \#2019GantiPresiden action are honest, clean, and sincere people. Thus, hyperreality provides a new kind of identity, that supporters of the \#2019GantiPresiden movement are high-integrity people to build nations with praiseworthy moral values. Then, those who will choose a new president are also certainly included in the group. Where the intended target is the free voters, this identification can undoubtedly be a commodity of consumption in itself for the audience.

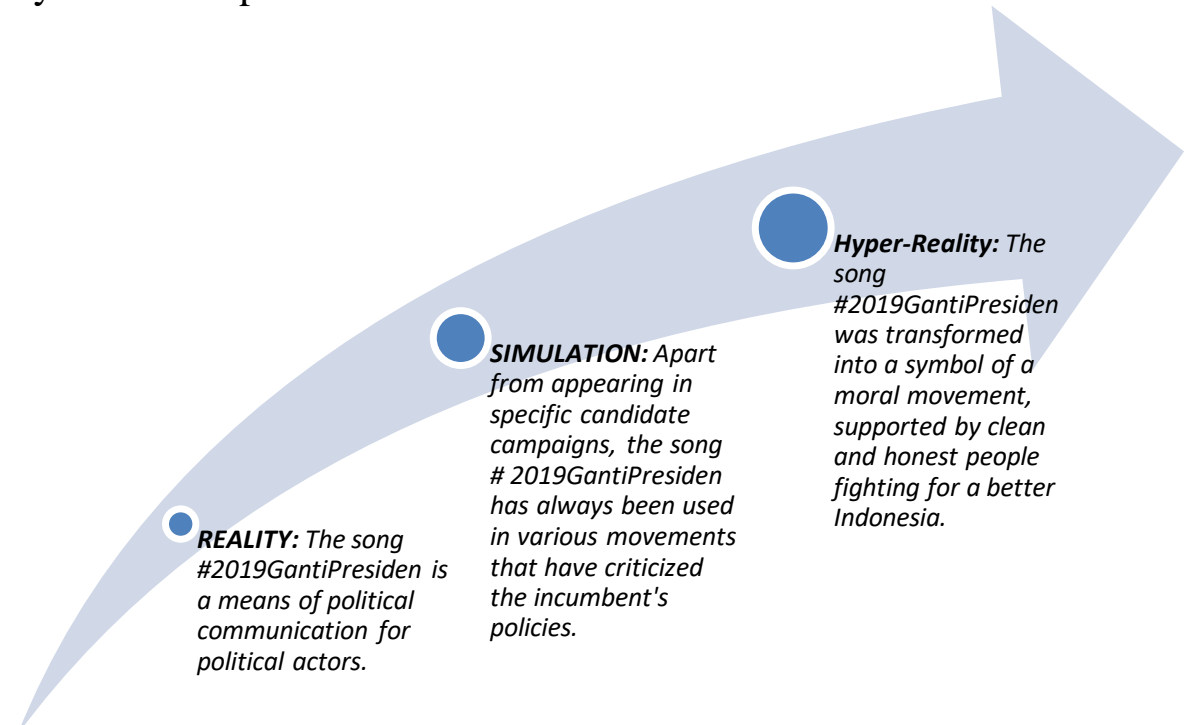

Figure 1. Hastag \#2019GantiPresiden in Simulacra flow

Second, this research analyzes with media text Analysis on \#2019GantiPresiden. Related coverage of the \#2019GantiPresiden movement, especially on online news pages throughout 2018-2019, tends to give a positive impression. In various news texts on online pages, the word selection in the headlines always builds a positive image for the \#2019GantiPresiden movement. For example, a webpage on detik.com was titled "Mardani attends the Declaration of Volunteers \#2019GantiPresiden in Australia" (23/07/2018) (Ibrahim, 2019). Another example also existed on the online page of Republika, entitled "The \#2019GantiPresiden as the first step to improve the fate of the Nation (26/5/2018) (Gerakan \#2019GantiPresiden Langkah Awal Memperbaiki Nasib Bangsa, 2018).

Of the two news, none of the press gives a negative image or at least a critique of the \#2019GantiPresiden movement. The \#2019GantiPresiden movement is reputed as something extraordinary, phenomenal, and historical. It does not become an anomaly 
when the \#2019GantiPresiden movement is reported without criticism as the subject to illustrate the event also has its interests (Lotan, 2019). Indeed, the news sources always have an association with the challenger's party, not neutral, or even from the prefigure (Ulfah \& Barry, 2019). With the position of this kind of news subject, the arrangement of news texts is undoubtedly easy to suspect because the majority only contains the flattery of the \#2019GantiPresiden movement.

Readers are invited to legitimize the \#2019GantiPresiden movement as a historical thing and become an image of the public's expectations of the figure carried on by the \#2019GantiPresiden movement. On the konfrontasi.com page, there is a piece of fairly unique news titled "Academics: \#2019GantiPresiden no need to be researched (6/7/2019)" (Akademisi: Gerakan \#2019GantiPresiden Tak Perlu Dirisaukan, 2019). This news was positioned through the viewpoint of academics and target readers who may address the world of education and also highlights the movement of \#2019GantiPresiden. With this kind of position, the reader is invited to assume that \#2019GantiPresiden movement has a strong foundation of academic theory. So, the negative assumptions about the emotional \#2019GantiPresiden movement and the Makar movement can be shaken or at least covered by this.

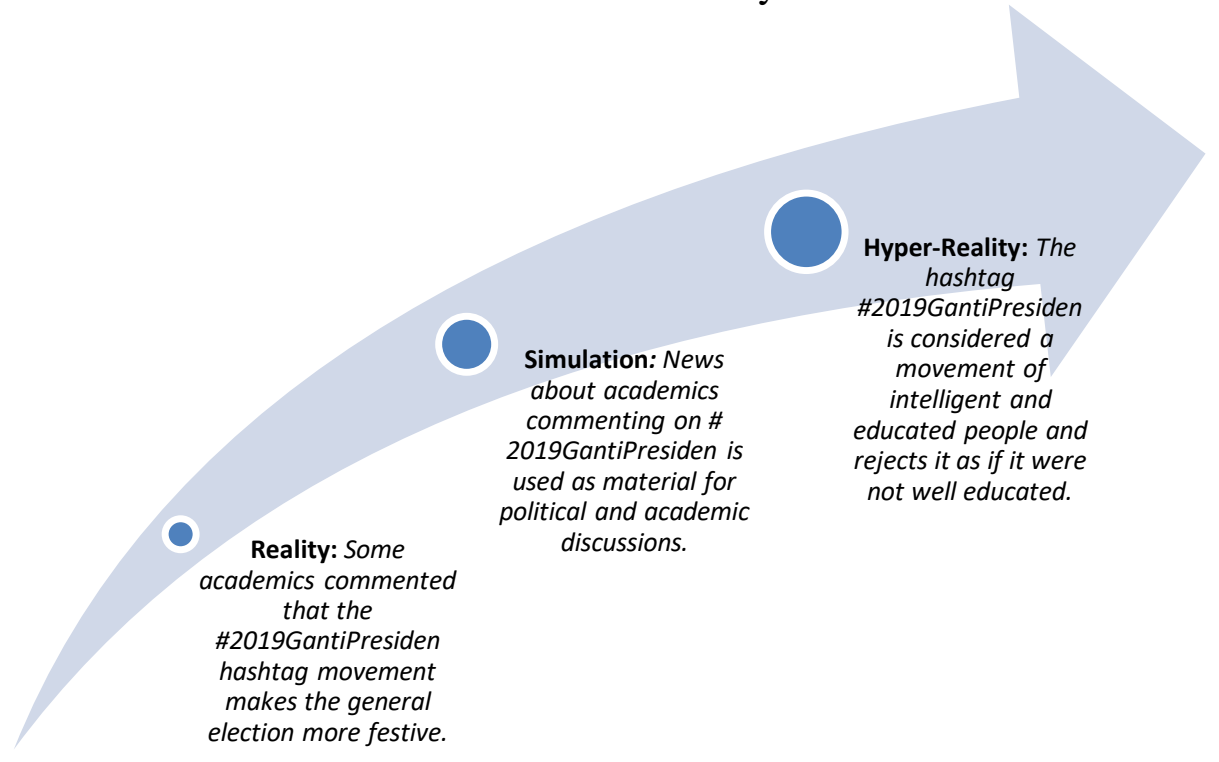

Figure 2. \#2019GantiPresiden movement in Simulacra flow

On that basis, it is not excessive if \#2019GantiPresiden is said to be a successful political movement. The media's coverage related to the \#2019GantiPresiden movement turns out to provide a positive image. The opinions that are often in the news texts that have mentioned are about the many participation of various layers of the society become evidence of the support and expectations of the public to the Invite the reader to agree on the opinion. Inevitably this becomes a distinct advantage, and considering the purpose of this \#2019GantiPresiden itself is to influence the free selector/floating selector to finally not select the incumbent.

Third, analyzing from the meaning, the song 2019 Ganti President as it is known as real music and politics are two different things. Similarly, the involvement of music in politics, in this case, especially in political campaigns, always raises questions about which is more strongly depicted in public (Fadillah, 2017). Therefore, it will feel wrong 
if one specifies the song 2019 Ganti President as just a political event regardless of the fundamental values of music as entertainment. The song 2019 Ganti Presiden may be a sign for the political campaign of the \#2019GantiPresiden movement. However, the song 2019 Ganti Presiden's popularity can backfire in creating the image and sign that want to be produced. Indeed, it is difficult not to consider the song 2019 Ganti President as a successfully viral song ringing in the head of the supporters of one of the candidates. The song's popularity can be simulated only as viral music and able to present a large amount of mass in a variety of \#2019GantiPresiden actions. Yet, what if this would instead make the song 2019 Ganti President into an entertainment product instead of being a campaign media as the purpose of the \#2019GantiPresiden movement? In Simulacra's conception, this could have occurred that the public received and convinced the song 2019 Ganti Presiden as a music event (Fadillah, 2014).

This kind of confusion is very likely to happen even though the news in the mass media is so full of political charge. Moreover, the sheer history of viral music on a limited political stage is just an entertainment event that can be considered significant. In a variety of possible simulations, hence, the meaning of the song 2019 Ganti President is establishing itself as a political campaign tool and not just a music concert alone.

This paper has previously described \#2019GantiPresiden analysis in the conception of Simulacra, any possible indication of what might be given, and the hyperreality of what may have occurred in its purpose as a political campaign medium. Furthermore, given one of the critical points in the context of the Simulacra is a signed game, a sign of the beginning of the song 2019 Ganti Presiden as a media campaign reflected in its goal to support the incumbent in the 2019 elections, becomes essential points to avoid biased meanings that may be publicly accepted. The song 2019 Ganti Presiden was successful as an entertainment product and as a political event. Political coverage can also appear because the song 2019 Ganti President is not only ordinary music.

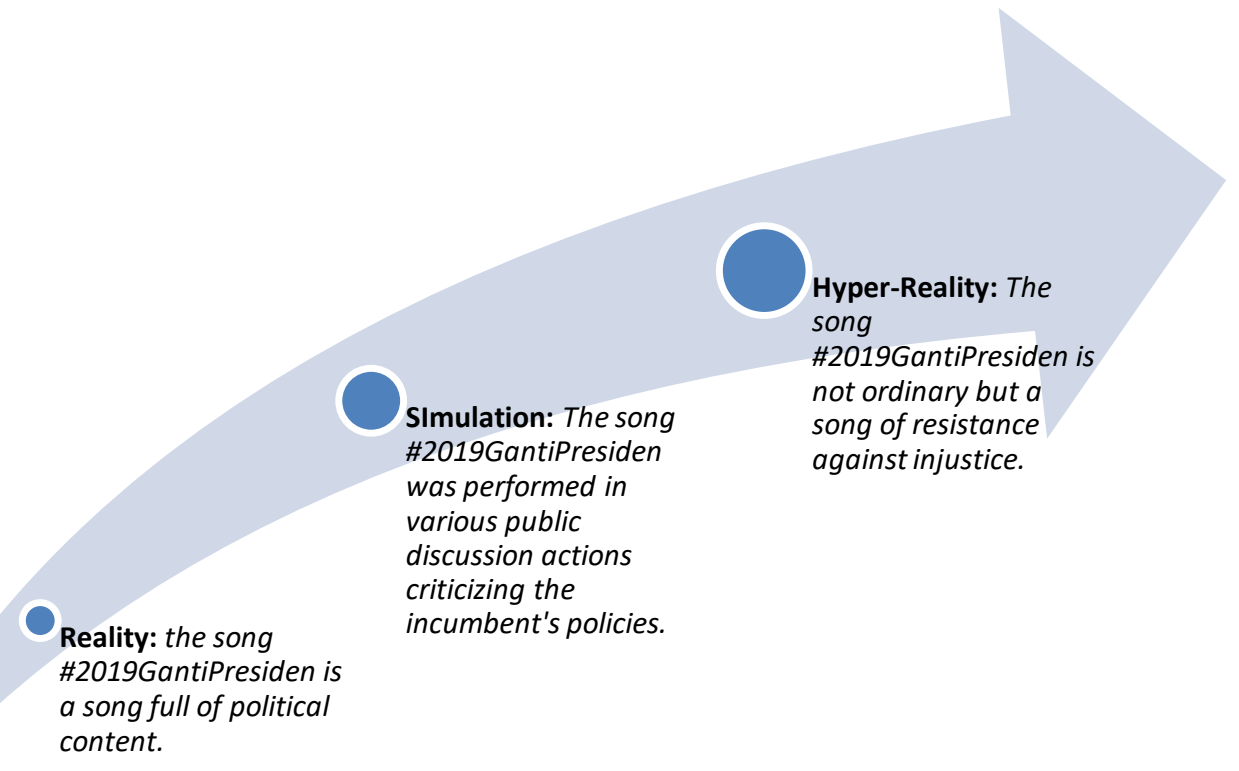

Figure 3. Song \#2019GantiPresiden movement in Simulacra flow 
The gap in which the separators divided means that the song 2019 Ganti President was specially composed to increase the sense of political campaigns \#2019GantiPresiden. The song 2019 Ganti President was established as a political campaign, and the song was not impressed only as music sung by many people. The song explicitly invites the listeners not to elect an incumbent, as implied in its lyrics. Furthermore, the song was also sung when the \#2019GantiPresiden campaign took place jointly by artists and spectators who attended. This activity can be said to strengthen the meaning of \#2019GantiPresiden and the song 2019 Ganti President as a political campaign. The people who sang the song will undoubtedly be associated as the supporters of the incumbent's rival.

\section{Conclusion}

Based on the analysis results through the media theory and text, the following outcomes can be drawn. First, the song 2019 Ganti Presiden and the \#2019GantiPresiden movement managed not only to be a regular social media movement but a simulation producing a series of signs. The first sign is in line with the purpose of \#2019GantiPresiden itself, which became a mass movement to overthrow the incumbent in the 2019 elections. Through this sign, the thing to show to society is the high community support to fight the incumbent.

Second, exposure in the mass media is proof that the smooth simulation process is running. Media feels cooperative because it gives a series of positive imagery in the news that lifts the theme of \#2019GantiPresiden. In various news, the media associate the audience present as a reflection of the public's expectations of the incumbent rival.

Third, the \#2019GantiPresiden movement explained the constellations of the 2019 politics during the presidential election of 2019, especially in the agenda of the political campaign. Although the song 2019 Ganti President has a goal like every music concert in general -as a medium to attract the masses, however, the song 2019 also formed a sign for the community.

Fourth, through the perspective of Foucault, it can be said that the artist who contributed to the \#2019GantiPresiden movement and also sang the song 2019 Ganti President attempted to be a sign of representatives of certain groups/classes. The founder can be a form of success of a particular power era, and this is what seems to be carried in the \#2019GantiPresiden movement to invite many people who come. On these points, the author believes that the \#2019GantiPresiden movement has produced a series of simulations that are primarily an image of public support to the incumbent's rivals in the 2019 presidential election. The simulation process will present a more or less hyperreality effect to increase the incumbent rival bargaining position in the 2019 presidential election, especially among the free voters.

The advice that can be given based on the results of this study is: first, The government can provide hashtag movements on social media and music as a media cultural strategy in Indonesia for the future, as well as a form of supporting the creative industry in Indonesia. It is unfortunate that in the future, music involvement in politics in Indonesia is considered a political campaign medium. Second, the use of music in a political campaign should be reduced. The dependence on music as a political campaign media will undoubtedly add to the burden of political campaign expenses. This is added with the absence of accurate data that ensure that music can boost the acquisition of votes in the elections. Third, it would be better to not only make music as a political campaign medium, rather as a new tool for community attention (Jandevi, 2019). This is 
because the function of music is extensive and not limited to attracting public attention. Music will still contain invitations to spur the community's political participation further.

\section{References}

\#2019GantiPresiden. (2018). 2019 ganti Presiden. YouTube. https://m.youtube.com/watch?from=singlemessage \&feature $=$ share \&v=8v30O9U3 Bs\&isappinstalled $=0$

Akademisi: Gerakan \#2019GantiPresiden Tak Perlu Dirisaukan. (2019). Konfrontasi. https://www.konfrontasi.com/content/politik/akademisi-gerakan2019gantipresiden-tak-perlu-dirisaukan

Baudrillards, J. (1988). Selected Writings (Mark Poster (Ed.)). Stanford University Press.

Baudrillards, J. (2018). Analysis Of Consumption Cultural Studies Essay. UKEssays.Com.

Douglas Kellner. (2007). Jean Baudrillard. Stanford Encyclopedia of Philosophy. https://plato.stanford.edu/entries/baudrillard/

Eriyanto, E. (2001). Sara Mills. Analisis Wacana.

Fadillah, D. (2014). Strategi komunikasi pembentukan budaya organisasi. Humanika, 14(1). https://doi.org/https://doi.org/10.21831/hum.v14i1.3327

Fadillah, D. (2017). Pola Komunikasi Internal Brajamusti Menjelang Pilkada $\begin{array}{llll}\text { Kotamadya } \quad \text { Yogyakarta } 2017 . & \text { Informasi, }\end{array}$ https://doi.org/https://doi.org/10.21831/informasi.v47i1.14880

Fadillah, D. (2019). HYPER REALITAS SIMULAKRA TAGAR \#2019GANTIPRESIDEN DALAM PEMILIHAN PRESIDEN INDONESIA 2019. Profetik, 12(2), 249-260. https://doi.org/https://doi.org/10.14421/pjk.v12i2.1669

Fadillah, D. (2020a). Belt Road Initiative in the Simulacra Analysis (Indonesia - China Relationship in the Perspective of Indonesian Students in Nanjing City). ASPIKOM, 5(1), 63-71.

Fadillah, D. (2020b). HYPER REALITAS SIMULAKRA TAGAR \#2019GANTIPRESIDEN DALAM PEMILIHAN PRESIDEN INDONESIA 2019. Profetik: Jurnal Komunikasi, 249. https://doi.org/10.14421/pjk.v12i2.1669

Fadillah, D., Zhenglin, L., \& Hao, D. (2019). Social Media and General Elections in Malaysia 2018 and Indonesia 2019. Jurnal Komunikasi ISKI, 4(1), 1-8. https://doi.org/10.25008/jkiski.v4i1.255

Fitri, S. N. (2018). Pemilu Pros and Cons of the Hashtag Movement \# 2019GantiPresiden as a Means of Campaigns in Elections. Law Research Review Quarterly, 4(2), 284-303. https://doi.org/https://doi.org/10.15294/snh.v4i02.25488

Gerakan \#2019GantiPresiden Langkah Awal Memperbaiki Nasib Bangsa. (2018). Republika. http://politik.rmol.co/read/2018/05/26/341554/Gerakan\#2019GantiPresiden-Langkah-Awal-Memperbaiki-Nasib-Bangsa-

Handari, S. (2019). PROPAGANDA POLITIK PADA LAGU 2019 GANTI PRESIDEN (ANALISIS WACANA KRITIS TEUN A. VAN DJIK) [University of Muhammadiyah Malang]. http://eprints.umm.ac.id/id/eprint/47816

Ibrahim, G. M. (2019). Mardani Hadiri Deklarasi Relawan \#2019GantiPresiden di 
Australia. Detik. https://news.detik.com/berita/d-4128284/mardani-hadirideklarasi-relawan-2019gantipresiden-di-australia

J. Schor, Holt, B., \& Holt., D. (2000). The Consumer Society Reader. New Press.

Jandevi, U. (2019). New media for increasing political participation in Indonesia. International Journal of Communication and Society, 1(1), 1-8. https://doi.org/10.31763/ijcs.v1i1.19

Jean Baudrillard. (2017). The Consumer Society Myth and Structures. Sage Publication.

Kardi, D. D. (2018). Lirik Lagu 2019 Ganti Presiden: Awas Kursimu Nanti Tergusur. CNN Indonesia. https://www.cnnindonesia.com/nasional/20180521151937-20300004/lirik-lagu-2019-ganti-presiden-awas-kursimu-nanti-tergusur

Lotan, F. F. (2019). Making a positive internet through Socmed Agawe Guyub. International Journal of Communication and Society, 1(1), 9-16. https://doi.org/10.31763/ijcs.v1i1.22

Mansur, S., Saragih, N., Ritonga, R., \& Damayanti, N. (2021). Fake News on Social Media and Adolescent's Cognition. Jurnal ASPIKOM, 6(1), 29. https://doi.org/10.24329/aspikom.v6i1.827

Noeng Muhadjir. (1996). Metodologi Penelitian. Kualitatif. Rake Sarasisn.

Rijali, A. (2019). ANALISIS DATA KUALITATIF. Alhadharah: Jurnal Ilmu Dakwah. https://doi.org/10.18592/alhadharah.v17i33.2374

Strauss, C. (2003). Dasar-Dasar Penelitian Kualitatif: Tatalangkah dan Teknik-teknik Teorisasi Data. Pustaka Pelajar.

Style Voice. (2018). Aku Gak Mau Ganti Presiden. YouTube. https://m.youtube.com/watch?isappinstalled $=0 \&$ feature $=$ share $\& v=-$ xhgCdZcs\&from $=$ singlemessage

Sujoko, A. (2019). Komunikasi Politik Gerakan \#2019GantiPresiden. Jurnal Komunikasi Islam, 9(1), 36-57. https://doi.org/10.15642/jki.2019.9.1.36-57

Syahputra, I. (2017). DEMOKRASI VIRTUAL DAN PERANG SIBER DI MEDIA SOSIAL: PERSPEKTIF NETIZEN INDONESIA. Jurnal ASPIKOM, 3(3), 457. https://doi.org/10.24329/aspikom.v3i3.141

Ulfah, M., \& Barry, A. (2019). Indonesia Leader Forum, post-truth and political interests in social media and television. International Journal of Communication and Society, 1(1), 17-25. https://doi.org/10.31763/ijcs.v1i1.18

Yuliarti, M. S. (2020). Democracy and New Media: Capturing Masculinity in Online News About Election Selfie. Jurnal ASPIKOM, 5(1), 27. https://doi.org/10.24329/aspikom.v5i1.440 